\title{
Attitudes of secondary teacher trainees towards entrepreneurial education
}

\author{
Ravi Shankar Gairola*
}

\author{
* S.N. College of Education, \\ Jagadhri, India. \\ E-mail: \\ gairola.ravi80@gmail.com \\ Article Info \\ Received: 10.12.2019 \\ Revised: $\quad$ 11.12.2019 \\ Accepted: 12.12.2019
}

\section{How to cite}

Gairola, R. S. (2019). Attitudes of secondary teacher trainees towards entrepreneurial education. Research in Educational Policy and Management, 1(1), 44-54.

\begin{abstract}
The present study aimed to analyze the attitudes of secondary teacher trainees towards entrepreneurial education. The sample of the present study comprised 100 Secondary teacher trainees from Bachelor of education (B. Ed.) colleges of District Yamunanagar in India. In order to accomplish the objectives of the present study, the descriptive survey method was considered appropriate for gathering data. The questionnaire was developed by the author for assessment of attitudes of secondary teacher trainees towards entrepreneurial education. T-test was used to analyze the attitudes of teacher trainees on basis of gender, social background, and academic discipline. The results revealed that the secondary teacher trainees have generally positive attitudes towards entrepreneurial education.

KEYWORDS

Entrepreneurial education; attitudes; secondary teacher trainees.
\end{abstract}

\section{INTRODUCTION}

Entrepreneurship education has been one of the most prominent success stories in higher education over the last few decades. While the idea to develop entrepreneurs was largely some entrepreneurial component especially in their business curricula in the 1980. In the 1990s, exerted greater effort to promote and nurture entrepreneurship attempts at various levels has taken place to directly or indirectly promote entrepreneurship. Today there is no doubt that millions of people are deeply involved in entrepreneurial activities ranging from starting up new businesses, buying failed businesses, revitalizing and resurrecting family and old businesses as well as innovating new ventures. For instant, it has been spotted that the generation of this $21^{\text {st }}$ century has no doubt become the most largely entrepreneurial generation ever recorded in the 
history of mankind right from the time of industrial revolution. Entrepreneurship is also a mechanism by which many people enter the economic and social mobility. Entrepreneurs do not wait for someone else to make the decision, or solve the problem, or even ask for the problem to be solved; they recognize problems as opportunities and takes it upon themselves to solve them (Segumpan et al., 2012).

Moreover, entrepreneurship is a dynamic process of vision, change and creation. It requires an application of energy and passion towards the creation and implementation of new ideas and creative solution. In this light entrepreneurship is more than the mere creation of business. A form of supports is the development of entrepreneurial talent in educational institutions.

India's higher education system generates a large number of graduates every year. In recent year, India's population has grown very fast. Because of the history of India and its multicultural composition, it seems impossible to have a family planning policy like that of China in the near future. If the university with high entrepreneurial potentials gets proper training, they will have the best prospects for becoming "real" entrepreneurs. Entrepreneurship is a matter that involves everyone the government, society and the educational institution. If entrepreneurship education in India's higher education system cannot completely address major obstacles in the pursuit of national economic development and employment, at least it can offer a start.

\section{Concept of entrepreneurship}

Entrepreneurship is a global phenomenon. The future, to an even greater degree than the past, will be driven by innovation and entrepreneurship. It is time to more adequately develop entrepreneurial skills, attitudes and behaviors in our school systems as well as outside formal school systems, to reach across all ages as part of a lifelong learning process. These challenges of fragmentation are not new to economic development professionals. Social entrepreneurship is attracting growing amounts of talent, money, and attention. The entrepreneur in an advanced economy is an individual who introduce something new in the economy- a method of production not yet tested by experience in the branch of manufacturing, a product with which consumers are not yet familiar, a new source of raw material or of new markets and the like (Schumpeter, 2008). An entrepreneur is the one who always searches for change, responds to it and exploits it as an opportunity. Innovation is the specific tool of entrepreneurs, the means by which they exploit changes as an opportunity for a different business or different service (Drucker, 2006). Social entrepreneurship is attracting growing amounts of talent, money, and attention. But along with its increasing popularity has come less certainty about what exactly a social entrepreneur is and does. As a result, all sorts of activities are now being called social entrepreneurship. Some say that a more inclusive term is all for the good, but the authors argue that it's time for a more rigorous definition (Martin and Osberg, 2007). 


\section{Concept of attitude}

The most general and simplest view is that attitudes are likes and dislikes individuals. Attitude as the degree of positive or negative affect associated with some psychological object. Attitudes are general evaluation people make about themselves, other persons, objects, and issues. In other words, attitudes involve lasting likes and dislikes, preference and aversions, towards specific aspects of the external word. Attitudes are enduring mental representation of various features of the social or physical world. They are acquired through experience and exert a directive influence on subsequent behavior (Kumar, 2005).

\section{Attitude of teacher trainees towards entrepreneurship}

The teacher is the most important element of an education system. Teachers' attitudes towards their profession are usually related with their enjoying their profession, dedicating themselves to their profession, being aware that their profession is socially necessary and important, and believing that they need to improve their profession, and so, themselves, continuously. Entrepreneurship learning is an experiential process which highly requires students to practice real roles and tasks of an entrepreneur and deal with the challenges associated with managing a new venture. Teachers play critical roles in creating such a pragmatic and social interactive environment which improves students' entrepreneurial selfefficacy through mastery experiences, vicarious learning, verbal persuasion and social support. Entrepreneurship is the dynamic process of creating incremental wealth. The wealth is created by individuals who assume the major risks in terms of equity, time and/or career commitment or provide value for some product or service. The product or service may or may not be new or unique, but value must somehow be infused by the entrepreneur by receiving and locating the necessary skills and resources (Hisrich et al., 2005).

\section{Justification of the study}

Entrepreneurial attitude is considered as important factor affecting the intention to step in to the process of entrepreneurship. Teaching and learning about entrepreneurship involve developing knowledge, skills, attitudes and personal qualities appropriate to the age and development of the pupils at the level of secondary education. Entrepreneurship teaching will aim to foster in the pupils those personal qualities such as creativity, spirit of initiative and independence that contribute to the development of an entrepreneurial attitude, which will prove useful in their life and in every working activity. In this phase, autonomous and active forms of learning should be developed.

Moreover, this teaching provides early knowledge of and contact with the world of business and some understanding of the role of entrepreneur in the community. Entrepreneurial attitudes can be encouraged in young people throughout their educational path. This type of teaching can be particularly effective if introduced in a structured why in the education system, starting from an early age. Keeping in mind the conceptual framework and a little research conducted in this area. Therefore, the investigator thought it worthwhile to 
undertaken his study to assess the attitude of teachers towards entrepreneurial education. So, that some light may be thrown on the relationship of gender, social background and discipline teacher trainees. Does gender and discipline jointly produce the differences in the attitude of teachers towards entrepreneurial education? Does gender affect the attitude of teachers towards entrepreneurial education? Does discipline generate differences in attitude of teachers towards entrepreneurial education? In order to arrive at the solution of the above research questions, the investigator selected and designed the present study.

\section{Objectives}

1. To study the nature of attitude towards entrepreneurial education of teacher trainees.

2. To compare and assess the attitude teacher trainees towards entrepreneurial education with respect to;
a) Gender
b) Social background
c) Academic discipline.

\section{Hypotheses}

1. There will be no significant difference in the attitude of male and female teacher trainees towards entrepreneurial education.

2. There will be no significant difference in the attitude of urban and rural teacher trainees towards entrepreneurial education.

3. There will be no significant difference in the attitude of science, arts and commerce teacher trainees towards entrepreneurial education.

\section{Delimitations of The Study}

The study was delimited to Yamunanagar District of Haryana state in India. 100 teacher trainees studying in the different colleges of education participated in the study. The variables were entrepreneurial education, gender, social background and academic discipline.

\section{METHODOLOGY}

\section{Participants}

The present research was conducted in District Yamunanagar of Haryana State. All teacher trainees's studying in Bachelor of education (B.Ed.) Colleges, situated in Yamunanagar district constituted the population for present study. The sample has been selected into different phases; in the first phase District Yamunanagar of Haryana state has been selected. In the second phase, all the colleges of education District Yamunanagar were listed. Out of these, three colleges of education were selected purposively. Finally, sample of 100 teacher Trainees of Bachelor of education (B.Ed.) department, from three colleges were selected through random sampling method. The details of sample break up have been given in the Table 1. 
Table 1: Distribution of study participants by gender and colleges of education.

\begin{tabular}{|l|c|c|c|}
\hline \multicolumn{1}{|c|}{ Name of Colleges of Education } & Males (n) & Females (n) & Total (n) \\
\hline Ganesh College Of Education & 10 & 19 & 29 \\
\hline Jankiji College Of Education & 03 & 07 & 10 \\
\hline Geetanjali college of Education & 27 & 34 & 61 \\
\hline Total (n) & 40 & 60 & 100 \\
\hline
\end{tabular}

\section{Study design and data collection tool}

In the present study, the researcher was used the descriptive survey method. To collect the data related to attitude of teacher trainees towards entrepreneurial education, the researcher developed and used the Attitude of Teacher Trainees towards Entrepreneurial Education Scale.

\section{Scale Development}

For preparing the Attitude of Teacher Trainees towards Entrepreneurial Education Scale the researcher consulted different sources in the relevant literature. The preliminary form of scale has 40 items spread over five dimensions for measuring teacher trainees' entrepreneurial attitude. The dimensions were Initiative, Problem solving, Commitment to work, Persistence, Persuasion. Each item has 5 alternative responses: Strongly Agree (SA), Agree (A), Neutral (N), Disagree (DA) and Strongly disagree (SD). The preliminary draft was passing through different phases of try out and revision in order to ensure its consistency and purports to measure its content validity. Finally, 15 items were deleted. So, the final draft of the scale consists of 25 items distribution over 5 dimensions on a five point Likert type scale.

The investigator made a pilot survey for validate the developed tools. For that the preliminary draft of questionnaire was prepared keeping in mind the nature and objectives of the present study consist of 40 items in all. The investigator then conducted preliminary try out with a group of 20 secondary teacher trainees. After getting the responses necessary modification has been done few items were removed because of level of difficulty and language. This was taken as reliability of the questionnaire.

The validity of the questionnaire was examined with the help of content validity. Content validity is based on judgment of several subject experts and test specialists by careful analyses of instructional objectives and actual subject matter studied. A copy of questionnaire was distributed to language, subject matter and technical experts in the concerned field in order to remove the discrepancies in any areas for validation. The experts in the field of computer education and language were requested by investigator for having a look at the questionnaire and also to give their valuable suggestions and opinion regarding the improvement and 
modification of the questionnaire. Depending upon the suggestions, some items were put together, some were added and some were excluded. Finally, twenty-five (25) items were retained in the final form of scale spread over five dimension in a five point Likert scale.

\section{Content of the scale}

There are 25 items in the Attitude of Teacher Trainees towards Entrepreneurial Education Scale. They are related to five major aspects of entrepreneurial attitude namely; Initiative, Persistence, Commitment to work, Problem solving and Persuasion. The items are such that they are centered on entrepreneurial attitude of Teacher Trainees. It is a 5 points rating scale measuring the use of the teachers' entrepreneurial attitude responding to each item ranging from ' 1 ' for 'strongly disagree' to ' 5 ' for 'strongly agree' for positive response and ' 1 ' for 'strongly agree' to ' 5 ' for 'strongly disagree' for negative response. The sum of the ratings against all the 25 items constitutes the score on teacher entrepreneurial attitude scale of the Teacher Trainees. The maximum possible score is 125 and the minimum is 25 . The dimensions and the distribution of items were given in Table 2.

Table 2: Dimensions and distribution of items in the Attitude of Teacher Trainees towards Entrepreneurial Education Scale

\begin{tabular}{|c|l|c|l|}
\hline No. & \multicolumn{1}{|c|}{ Dimensions } & $\begin{array}{c}\text { Number of } \\
\text { Items }\end{array}$ & $\begin{array}{c}\text { Distribution of items } \\
\text { by dimensions }\end{array}$ \\
\hline 1 & Initiative & 5 & $1,3,11,12,16$ \\
\hline 2 & Problem solving & 5 & $2,8,17,20,25$ \\
\hline 3 & Commitment to work & 5 & $4,5,7,13,14$ \\
\hline 4 & Persistence & 5 & $6,9,10,18,19$ \\
\hline 5 & Persuasion & 5 & $15,21,22,23,24$ \\
\hline & & $\mathbf{2 5}$ & \\
\hline
\end{tabular}

\section{Statistical Analysis}

The descriptive statistics were computed such as measure of central tendencies, measure of dispersion, skewness and kurtosis, also t-test was used.

\section{ANALYSIS AND INTERPRETATION OF THE DATA}

\section{Description of The Data}

The mean, median, mode and standard deviation were worked out to study the nature of the total sample in relation to entrepreneurial attitude of secondary teacher trainees towards entrepreneurial education. Further variance, skewness and kurtosis were computed to see the 
trend of departure of the sample from normal distribution and nature of data. The detail analysis and interpretation has been given in the table 3.

Table 3: Descriptive statistics of attitude of secondary teacher trainees towards entrepreneurial education

\begin{tabular}{|l|c|}
\hline N & 100 \\
\hline Mean & 102.25 \\
\hline Median & 101 \\
\hline Mode & 93 \\
\hline Standard Deviation & 11.01 \\
\hline Variance & 121.23 \\
\hline Skewness & 0.106 \\
\hline Kurtosis & -0.86 \\
\hline
\end{tabular}

Table 3 reveals that mean, median, mode and standard deviation variance, skewness and kurtosis of secondary teacher trainees attitude towards entrepreneurial education. The Mean is 102.25 , Median is 101.00 , Mode is 93.00 , standard deviation is 11.01 , and variance is 121.23 . The trend of results shows that there is a slightly variance from the average score. The value of skewness is 0.106 . It shows that the data have been positively skewed. The value of kurtosis (0.86 ) is less than the normal distribution i.e. 0.286 . Thus, it is a platykurtic nature.

\section{Analysis and Interpretation based on t- test}

In order to find out the significance difference between mean score of secondary teacher trainees attitude towards entrepreneurial education with respect to gender (male- female), social background (rural, urban), academic discipline (science, arts \& commerce). t- test was computed. The details of analysis and interpretation have been given in the following headings.

\section{Data analysis by gender}

In order to find out the significance difference in the mean score of male and female secondary teacher trainees attitude towards entrepreneurial education. $t$ - test was computed. The details analysis and interpretation has been given in the table 4.

Table 4: Significance Difference in the Mean Score of Male and Female Secondary Teacher Trainees Attitude towards Entrepreneurial Education

\begin{tabular}{|l|l|l|l|l|l|l|}
\hline Groups & N & Mean & SD & SED & t- ratio & $\begin{array}{l}\text { Level of } \\
\text { sig. }\end{array}$ \\
\hline Male & 40 & 97.27 & 9.37 & \multirow{2}{*}{2.04} & $4.06^{*}$ & $\mathrm{p}>0.05$ \\
\hline Female & 60 & 105.56 & 10.83 & & & \\
\hline
\end{tabular}


\begin{tabular}{|l|l|l|l|l|l|l|}
\hline & & & & & & \\
\hline
\end{tabular}

*significance at 0.05 level of significance with table value $=1.98$

In the above Table 4 reveals that mean scores and the standard deviation scores of male and female secondary teacher trainees attitude towards entrepreneurial education are 97.27, 105.56 and $9.37,10.83$ respectively. The calculated t-ratio (4.06) of male and female secondary teacher trainees' attitude towards entrepreneurial education is significant at 0.05 level of significance. It shows that there is a significant difference in the mean scores of male and female secondary teacher trainees attitude towards entrepreneurial education. Further in the comparison of mean score it clears that female secondary teacher trainees exhibited better attitude towards entrepreneurial education as compare to male secondary teacher trainees.

Therefore, the null hypothesis no.1 which is stated earlier that there will be no significance difference in the attitude of male and female secondary teacher trainees towards entrepreneurial education is not retained.

\section{Data analysis by locale (rural and urban secondary teachers)}

In order to find out the significance difference in the mean scores of rural and urban secondary teacher trainees attitude towards entrepreneurial education t- test was computed. The details analysis and interpretation have been given in the Table 5 .

Table 5: Significance Difference in the Mean Score of rural and urban Secondary Teacher Trainees Attitude towards Entrepreneurial Education

\begin{tabular}{|l|l|l|l|l|l|l|}
\hline Groups & $\mathrm{N}$ & Mean & SD & SED & t- ratio & $\begin{array}{l}\text { Level of } \\
\text { sig. }\end{array}$ \\
\hline Rural & 48 & 100.68 & 11.39 & \multirow{2}{*}{2.20} & $1.37^{* *}$ & $\mathrm{P}<0.01$ \\
\hline Urban & 52 & 103.69 & 10.54 & & & \\
\hline
\end{tabular}

**Not significance at 0.01 level of significance with table value $=2.63$

Table 5 indicates that mean scores and the standard deviation scores of rural and urban secondary teacher trainees' attitude towards entrepreneurial education are100.68, 103.69 and $11.39,10.54$ respectively. The calculated t- ratio (1.37) of rural and urban secondary teacher trainees' attitude towards entrepreneurial education is not significant at 0.01 level of significance. It shows that there is no significant difference in the mean scores of rural and urban secondary teacher trainees attitude towards entrepreneurial education. Therefore, the null hypothesis no. 2 which is stated earlier that there will be no significant difference in the attitude of rural and urban secondary teacher trainees towards entrepreneurial education is retained. 


\section{Data analysis by locale by academic stream (Arts, commerce and science teachers)}

In order to find out the significance difference in the mean scores of academic stream of secondary teacher trainees attitude towards entrepreneurial education. $t$ - test was computed. The details analysis and interpretation have been given in the table 1.4

Table 1.4: Significance Difference in the Mean Scores of Arts, Commerce and Science Secondary Teacher Trainees Attitude towards Entrepreneurial Education

\begin{tabular}{|l|l|l|l|l|l|l|l|}
\hline $\begin{array}{l}\text { Academic } \\
\text { stream }\end{array}$ & N & Mean & SD & SED & Groups & t- ratio & $\begin{array}{l}\text { Level } \\
\text { of sig. }\end{array}$ \\
\hline Arts & 55 & 100.98 & 11.27 & 2.52 & I VS II & $1.24^{* *}$ & $\mathrm{P}<0.01$ \\
\hline Commerce & 26 & 104.11 & 10.25 & 3.01 & I VS III & $0.79^{* *}$ & $\mathrm{P}<0.01$ \\
\hline Science & 19 & 103.36 & 11.31 & 3.28 & II VS III & $0.22^{* *}$ & $\mathrm{P}<0.01$ \\
\hline
\end{tabular}

$* *$ Not significance at 0.01 level of significance with table value $=2.64$

From the table 1.4 reveals that mean scores and the standard deviation scores of arts and commerce of secondary teacher trainees attitude towards entrepreneurial education are100.98, 104.11 and $11.27,10.25$ respectively. The calculate t- ratio (1.24) of arts and commerce secondary teacher trainees' attitude towards entrepreneurial education is not significant at 0.01 level of significance. It shows that there is a no significant difference between mean scores of arts and commerce secondary teacher trainees attitude towards entrepreneurial education.

Further 1.4 shows that mean scores and the standard deviation scores of arts and science of secondary teacher trainees attitude towards entrepreneurial education are100.98, 103.36 and $11.27,11.31$ respectively. The calculated t- ratio (0.79) of arts and science secondary teacher trainees' attitude towards entrepreneurial education is not significant at 0.01 level of significance. It means that there is a no significant difference between mean scores of arts and science secondary teacher trainees attitude towards entrepreneurial education.

It looks from table 1.4 reveals that mean scores and the standard deviation scores of commerce and science of secondary teacher trainees attitude towards entrepreneurial education are $104.11,103.36$ and $10.25,11.31$ respectively. The calculate t- ratio $(0.22)$ of arts and commerce secondary teacher trainees' attitude towards entrepreneurial education is not significant at 0.01 level of significance. It shows that there is a no significance difference between mean score of secondary teacher trainees attitude towards entrepreneurial education.

Therefore, the null hypothesis No.3 which is stated earlier that there will be no significance difference in the attitude among Arts, commerce and science secondary teacher trainees towards entrepreneurial education is retained. 


\section{CONCLUSION}

On the basis of the analysis, interpretation and result as given in the previous chapter the following main findings have been drawn:

1. It shows that there is a significant difference in the mean scores of male and female secondary teacher trainees attitude towards entrepreneurial education. Further in the comparison of mean score it clears that female secondary teacher trainees exhibited better attitude towards entrepreneurial education as compare to male secondary teacher trainees.

2. It shows that there is no significant difference in the mean scores of rural and urban secondary teacher trainees attitude towards entrepreneurial education.

3. It shows that there is a no significant difference among mean scores of arts, commerce and science secondary teacher trainees attitude towards entrepreneurial education.

\section{Educational Implications}

In the light of main findings of the study conversing the entrepreneurial attitude of teacher trainees, we can list down some educational implications of this research work:

1. The teacher trainees have to be educated on natural resources therefore; educational agencies are required to organize such type of programs which may cover the above mentioned areas selected to entrepreneurial. There is an urgent need to provide education and training about entrepreneurial to the teacher trainees.

2. The teacher trainees should also bear the responsibility to create positive attitudes among the students toward entrepreneurial education. Teachers hold the main responsibility to spread awareness among the students from primary level to higher level onwards.

3. Moreover, mass media such as radio, T.V. newspaper periodical, feature films and documentaries etc. can be used effectively in the expansion of entrepreneurship education among masses.

4. Thus only entrepreneurial education can develop an attitude towards entrepreneurial in student as well as in community as large, so that quality of our entrepreneurship will maintained.

\section{REFERENCES}

Drucker P. F. (2006). Innovation and Entrepreneurship. New York: HarperCollins.

Hisrich, R. D., Peters, M.P. and Shepherd, D. A. (2005) Entrepreneurship. (6th ed.), New York: McGraw-Hill Irwin.

Kumar, A. (2005). Psychology of Human Behavior. Retrieved 22-04-2019 from https://www.yumpu.com/en/document/read/22288365/ext-502-psychology-ofhuman-behaviour-csk-himachal-pradesh- 
Martin, R. L. and Osberg, S. (2007). Social Entrepreneurship: The Case for Definition. Retrieved 22-06-2019 from

https://ssir.org/articles/entry/social_entrepreneurship_the_case_for_definition

Schumpeter, J. A. (1949). Change and the entrepreneur: Postulates and patterns for entrepreneurial history. Harvard University Press.

Segumpan, R. G., Soraya, J. and Zahari, A. B. (2012). Attitude Towards Entrepreneurship Among Omani College Students Trained in Business. International Journal of Business and Behavioral Sciences, 2(4), 61-72. 